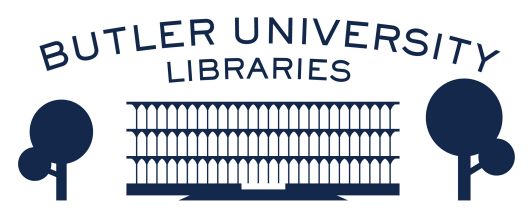

Journal of Hindu-Christian Studies

November 2014

\title{
Book Review: The Divine Body in History: A Comparative Study of the Symbolism of Time and Embodiment in St. Augustine and Rāmānuja.
}

Jon P. Sydnor

Emmanuel College, Boston

Follow this and additional works at: https://digitalcommons.butler.edu/jhcs

Part of the History of Religions of Eastern Origins Commons

\section{Recommended Citation}

Sydnor, Jon P. (2014) "Book Review: The Divine Body in History: A Comparative Study of the Symbolism of Time and Embodiment in St. Augustine and Rāmānuja.," Journal of Hindu-Christian Studies: Vol. 27, Article 16.

Available at: https://doi.org/10.7825/2164-6279.1588

The Journal of Hindu-Christian Studies is a publication of the Society for Hindu-Christian Studies. The digital version is made available by Digital Commons @ Butler University. For questions about the Journal or the Society, please contact cbauman@butler.edu. For more information about Digital Commons @ Butler University, please contact digitalscholarship@butler.edu. 
sometimes missing, hiding, not coming back, nowhere else-shines better in a world where we need not forget this Krishna about to return to the young woman waiting in the garden" (141). This reader wholeheartedly agrees, but still wonders does it merely shine more brightly, or might we not dare to go further and ask how it shines differently?

His Hiding Place is Darkness is a beautifully and skillfully written text and should be of interest to a wide variety of readers. In its "Acts," Clooney gives us one of the only extended studies of the Holy Word in the English language, and for this reason it makes a significant contribution for readers focused on
Hindu studies. In particular, it should be of interest to any Christian theologian (whether of comparative inclinations or not) concerned with the relationship between theological knowledge and the obstacles posed by modernity and religious pluralism. What of Hindu readers with theological commitments to Krishna? Their engagement with the book is essential if we are to further explore what it might mean to develop a Hindu-Catholic theopoetics.

Rico G. Monge

University of San Diego

\section{The Divine Body in History: A Comparative Study of the Symbolism of Time and Embodiment in St. Augustine and Rāmānuja. Ankur Barua. New York: Peter Lang, 2011, 253 pp.}

IN The Divine Body in History Dr. Ankur Barua of Cambridge University presents an incisive study in the comparative philosophy of religion. As the book proceeds, the line between philosophy of religion and theology blurs, making the book a significant contribution to comparative theology as well.

Dr. Barua addresses two themes in The Divine Body: time and embodiment. He then compares two influential theologians on these topics: Rāmānuja and Augustine. His choice of figures serves to correct the unstudied assumptions that Hindu thought is ahistorical and Christian thought is anti-body. Instead, Dr. Barua argues that Rāmānuja is carefully attentive to history and Augustine (particularly the later Augustine) valorizes embodiment as the intention of our Creator, the maker of all things visible and invisible. His choice of themes allows Dr. Barua to correct two common misinterpretations. His comparative method grants him insight into each thinker, read in the light of the other, making for a more powerful exposition.

Dr. Barua adopts the comparative method as a demand of our theological age. The contemporary theological context is irretrievably pluralistic, presenting theologians not only with "other" answers, but with "other" questions as well-questions they have never answered, or may never have asked. Thus, we find our religious selves in a context of otherness in which the old monological thought seems flat and ineffective. This new, interreligious universe demands multilogical thought best nurtured through dialogue among traditions (2). 
Comparison is more easily endorsed than executed, and every comparativist must adopt a method that allows comparison to emerge without erasing the compared. Dr. Barua strikes this balance by presenting Augustine's views on a topic first, then Rāmānuja's views on the same topic, as well as Rāmānuja's possible response to Augustine. Rāmānuja's response leads to Augustine's exposition of another doctrine, followed by Rāmānuja's exposition and response, in a kind of double-helix ascent through the nuances of time and embodiment (34).

Some religious studies theorists accuse comparativists of assimilating difference into sameness, like interreligious Borg against whom resistance is futile. Dr. Barua's highly nuanced and attentive presentation of Rāmānuja and Augustine individually, prior to comparison, establishes his contextualized understanding of both. His reference to the original languages of Sanskrit and Latin corroborates that contextualization. Fortunately, he does not leave them in that original context but re-contextualizes them in our contemporary world and their relationship to each other. In that relationship Dr. Barua finds reinvigorated relevance and amplified meaning. (7)

Turning to the comparative content of The Divine Body in History, Dr. Barua offers four theses. First, Augustine's and Rāmānuja's concepts of the body (corpus/sarira) differ: For Augustine if it an undividable physical entity; for Rāmānuja it is an entity subject to direct control by a consciousness. Second, for both theologians our embodiment does not cause our suffering; instead, our prioritization of bodily desires over devotion to God causes our suffering. Only through subordinating our embodiment to the divine does embodiment become enjoyable (239). Third, with regard to time, both theologians assign the origin of our suffering to the past, God's activity to the present, and a promised perfection of embodiment to the future. Fourth, for both theologians, human spiritual advance occurs within the divine body-the Body of Christ (which is the Church) for Augustine, and the body of Narayana (which is all of reality) for Rāmānuja. (34-35)

Throughout the body of his book, Dr. Barua generally presents Augustine and Rāmānuja separately. His discrete presentation of each theologian is influenced by the other, insofar as writing of both necessitates emphasizing certain analogous themes. When called for, however, Dr. Barua will present explicitly comparative sections dedicated to neither theologian, but to their theological relationship (56-57, 73-76, 131-132, 182-185, etc.). These are some of the most interesting sections of the book.

For example, by directly comparing Augustine's and Rāmānuja's doctrines of divine knowledge, he elicits aspects of each that might have remained concealed. For Augustine, divine foreknowledge is an acute problem in a "subsumptive linear" temporal universe consisting of past, present, and future. If God is omniscient, then humans may be coerced into doing what God foreknows we will do. In that case, we have no moral agency. Fatalism is the only appropriate designation of this situation. For Rāmānuja, operating within a cyclic temporal universe that relativizes past, present, and future, foreknowledge presents less of a problem. Instead, the karma of past lives and their influence on current life can generate accusations of fatalism. 
But Dr. Barua points out that neither theologian is fatalistic: For Augustine, God's foreknowledge of our free choice does not constrain that choice, any more than a parent's foreknowledge that her child will major in English constrains that choice. Similarly, for Rāmānuja, every individual soul (jivatman) has the ability to rise above or sink deeper within samsara, freely. More importantly, true knowledge of God frees the soul from its accumulated karma. So, every moment is a morally and spiritually free moment, according to both theologians. Human beings are not determined. We are agents, and faith heightens our moral and spiritual agency. (182-185)

Dr. Barua's book is an exercise in comparative philosophy of religion, so the next criticism may not be fair. Nevertheless, I will offer it: I would like to have seen more speculative philosophy of religion, or constructive comparative theology, in the book. Dr. Barua clearly possesses great analytical, philological, and comparative ability. His discrete presentations are sound and his comparison incisive. But incisive comparison begs for synthetic answers. Dr. Barua establishes that both Rāmānuja and Augustine value embodied, temporal existence. But how has his in-depth study of these two preeminent theologians transformed Dr. Barua's own experience of embodied, temporal existence? I would like for Dr. Barua to share that transformed knowledge, because the world needs that transformed knowledge. As Dr. Barua continues his academic investigations, I look forward to even more originality from this promising young philosopher.

Jon Paul Sydnor

Emmanuel College, Boston

\section{Hindu Theology and Biology. The Bhägavata Purāna and Contemporary Theory. Jonathan B. Edelmann. New York: Oxford University Press, 2012, 251pp.}

THERE are many works on Hinduism and Hindu Theology that offer an in-depth analysis of the tradition in the religious, anthropological, historical, and philosophical aspects, but few are the ones that engage the study of the sacred sources of Hindu tradition into a meaningful and careful dialogue with contemporary Western scientific thought. Jonathan B. Edelmann's book does precisely this, and more. The author critically analyses both, the theological discourse of the Bhāgavata Purāna and the scientific language used in the history of Darwinism to create possibilities of high standard academic "cross-pollination". The result is a fertile land in which the symbolical, teleological, and spiritual world of this Hindu text is maintained in all its richness, at the same time that it harmonizes in a mature way with evolutionary biology.

The author is aware of many of the presuppositions involved in bringing science and religion into dialogue. One of them is the stereotyped characterizations that have frequently surrounded both of these human practices since the dialogue between Christianity and modern evolutionary science began in the seventeenth century. Edelmann prepares the ground for the dialogue by 